\title{
INFA PERFORMANCE INDICATOR DIAGNOSTIC SYSTEM
}

\author{
Neumaier, I., Neumaierová, I.
}

Financial analysis is an essential tool for those interested in assessing the economic management situation of enterprises and subsequent decision making. The aim of this article is to demonstrate the capacity the IN Financial Analysis (INFA) system has to inform, i.e. its information capability. This is a tool that allows users to comprehensively assess the economic management of enterprises in that it causally links the indicators of financial controlling and risk controlling. We apply it to the best industrial enterprises in the Czech Republic in 2011 and 2012 and at the same time use the representative database of the Ministry of Industry and Trade of the Czech Republic.

JEL classification: M21

Keywords: Financial controlling; risk controlling; INFA financial analysis; industrial enterprises in the Czech Republic; foreign owners; domestic owners.

\section{Introduction}

The purpose of accounting data is to provide a true and fair view of the operation of an enterprise (see, for example Strouhal, 2013, for more about professional ethics in accounting). The core use of such data in managing an enterprise is to provide a financial analysis of that enterprise. The type of picture we get in relation to the economic management situation of an enterprise depends on the financial analysis used. A financial analysis should provide a holistic view of company performance and fulfil the role of a diagnostic tool. It is not enough to create an indicator collection - a system of indicators must be created. This means that indicators of performance cannot be taken at random and that even the most aggregate of views needs to have available to it a certain minimum number of indicators such that a picture of the overall financial performance of an enterprise can be generated. Individual indicators create elements without which an indicator system cannot carry out its function. Elements do not exist independent of each other, but are linked by relationships that must be respected.

Our aim is to present and apply the INFA performance indicator diagnostic system to an example: a comparison of the best private domestic industrial enterprises (enterprises with private domestic owners) and foreign private enterprises (enterprises with private foreign owners).

We draw on the following hypothesis:

The INFA financial analysis is able to judge the financial situation of an enterprise more comprehensively that the much-used (classic) financial analysis.

\section{The INFA method}

INFA is based on the following concepts (Neumaier, Neumaierová, 2002). Firstly, when considering company performance, it is necessary to interconnect the indicators of financial controlling and risk controlling, whilst at the same time having the option of a separate view. The indicator that provides the most aggregated embodiment of this interconnection is economic profit (Economic Value Added - EVA). An enterprise is sufficiently effective if it achieves positive economic profit. Secondly, it is necessary to separate the creation of company output (EBIT), its division and relationships between the time structure of assets and liabilities (see Figure 1). There is not one financial analysis model in the Czech Republic or abroad that includes the interconnection of these two concepts that developed in the minds of those that developed it over a number of years. 
INFA works with the managerial face of economic profit, which compares the return on equity achieved by an enterprise $(R O E=$ net profit/equity) and the alternative cost of equity, meaning the required return on equity with respect to the risk run $\left(r_{e}\right)$, and multiplies this so-called spread by the amount of equity $(E)$ :

$$
\text { EVA }=\left(\frac{\text { Net profit }}{\text { Equity }}-r_{e}\right) * \text { Equity }
$$

Positive economic profit assumes that when factors which influence ROE and re are at work, their positive influence on the return on equity prevails over the influence on risk.

We divide the influencing factors into three groups (see figure 1):

\section{Figure 1 Diagram of INFA}

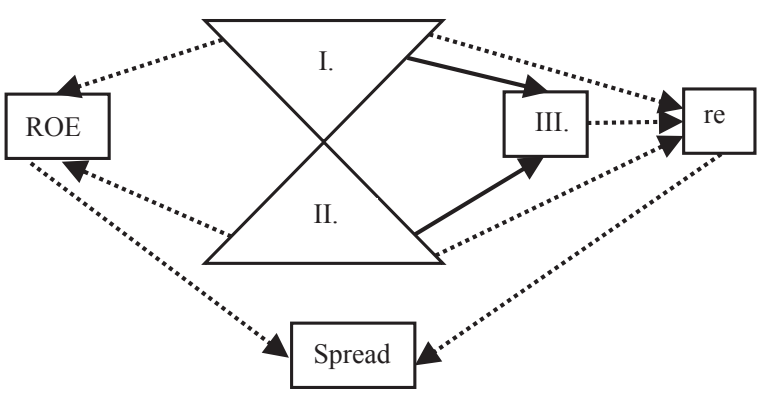

Source: Authors

The first group (I.) consists of those that influence the size of the output created by an enterprise. The most appropriate characteristic of company output is EBIT (earnings before interest and tax), because this quantity is not influenced by the size of company output intended for creditors (interest) and for the state (tax). The size of EBIT must be assessed in relation to the value of assets tied in the enterprise. The EBIT/assets (ROA) indicator shows the overall profitability of the enterprise and is known as the production power of the enterprise. The first group of indicators includes production power and indicators that outline the manner of its creation. Here there is a link between the values of financial accounting and in-house (managerial) accounting. Production power can be monitored from in-house centers (SBU) and products. High, stable production power acts positively on both ROE and re.

The second group (II.) includes factors that decide on the way in which the EBIT generated by the enterprise is divided among owners, creditors (meaning those that provide capital) and the state. The division of output is usually left at the company level, meaning that diverting capital to in-house units is not common. The relationship of three returns is important in setting the capital structure (the size of financial leverage) from the perspective of its effect on ROE: only production power (ROA) that leads to the return of interest-bearing sources (EBIT/equity + bank loans and bonds) that exceed the rate of interest will ensure the possibility to increase the return on equity (ROE) alongside rising indebtedness. If a company's production power is not sufficient (the relationship specified above does not apply), ROE worsens as a result of higher indebtedness. Financial leverage affects the size of risk (re) quite unambiguously: it invariably stands that higher indebtedness generates higher risk. With the rise of indebtedness comes a change in the division of EBIT to the detriment of the owners, because the part taken from those owners in the form of interest rises.

The third group (III.) comprises indicators that indicate the financial stability under which the creation and division of company output is played out. Indicators that represent the equilibrium of the system (the ability of an enterprise to pay its obligations to stakeholders on time) are the condition necessary for the functioning of the enterprise and have a significant influence on company risk. Standard liquidity (L3) is one of these. If L3 falls below the minimum (value 1), indicating negative net working capital, risk is increased to the maximum.

What is decisive is how the indicators of all the above-described groups act in aggregate on return on equity (ROE) and the degree of risk (re), meaning how the spread $(\mathrm{ROE}-\mathrm{re})$ rises or falls.

INFA has been used at the Ministry of Industry and Trade of the Czech Republic for more than two decades now. It is presented on the ministry's website, which is visited by entrepreneurs, analysts and students (http:// www.mpo.cz/dokument141226.html).

\section{Data}

In order to verify the hypothesis, we work with the aggregated data available at the Ministry of Industry and Trade of the Czech Republic's website: (http://www. mpo.cz/dokument141226.html). This is an example of the supra-company application of INFA and for this reason the appearance of INFA is as aggregated (brief) as possible with regard to the data available for analysis. What we are interested in is the best private industrial (economic-profit-generating) enterprises under domestic control and private enterprises under foreign control. We are interested in whether and how their financial performance differs. 
Table 1 Financial results of the best private industrial enterprises under foreign (F) and domestic (D) ownership in 2011 and 2012

\begin{tabular}{|l|r|r|r|r|}
\hline & \multicolumn{1}{|c|}{ F11 } & \multicolumn{1}{|c|}{ F12 } & \multicolumn{1}{c|}{ D11 } & D12 \\
\hline EVA (thousand CZK) & 57076260 & 104749459 & 10323773 & 16525225 \\
\hline Equity (thousand CZK) & 954961164 & 443127887 & 187136551 & 129787595 \\
\hline Spread (\%) & 11,26 & 23,64 & 9,87 & 12,73 \\
\hline re (\%) & 9,39 & 11,03 & 10,55 & 8,92 \\
\hline ROE (\%) & $\mathbf{2 0 , 6 5}$ & $\mathbf{3 4 , 6 7}$ & $\mathbf{2 0 , 4 4}$ & $\mathbf{2 1 , 6 6}$ \\
\hline ROA (\%) & $\mathbf{1 1 , 4 7}$ & $\mathbf{1 1 , 0 5}$ & $\mathbf{1 3 , 0 3}$ & $\mathbf{1 5 , 1 7}$ \\
\hline Revenues IAssets & $\mathbf{1 , 3 1}$ & $\mathbf{1 , 7 5}$ & $\mathbf{1 , 1 1}$ & $\mathbf{1 , 2 1}$ \\
\hline ROS (\%) & $\mathbf{8 , 7 3}$ & $\mathbf{6 , 3 2}$ & $\mathbf{1 1 , 7 2}$ & $\mathbf{1 2 , 5 2}$ \\
\hline Equity/Assets (\%) & $\mathbf{5 3 , 0 6}$ & $\mathbf{5 2 , 6 9}$ & $\mathbf{5 5 , 1 8}$ & $\mathbf{5 6 , 9 2}$ \\
\hline Interest-bearing sources/Assets (\%) & 59,16 & 60,32 & 61,68 & 65,55 \\
\hline Standard liquidity L3 & $\mathbf{2 , 3 6}$ & $\mathbf{2 , 1 9}$ & $\mathbf{1 , 9 0}$ & $\mathbf{1 , 8 0}$ \\
\hline
\end{tabular}

Source: http://www.mpo.cz/dokument141226.html

Table 1 shows the situation of private industrial (economic-profit-generating) domestic and foreign enterprises from the Ministry of Industry and Trade of the Czech Republic's database.

\section{Method of checking the hypothesis}

The method of checking the hypothesis involves comparing the information capability of output from the INFA financial analysis and the output of an analysis of relational indicators according to a classic financial analysis and noticing the differences.

The six indicators shown in Table 1 in bold print are the basis for comparing the information capability of INFA and a classic financial analysis. To ensure maximum comparability of the information capability of the analyses, the selection of indicators is made in such a way that the most important representatives of individual areas of a classic financial analysis are included, as are carrying indicators from the creation of company output, the division of company output and financial stability from INFA.

We evaluate the financial situation in 2012 in our illustrative example. Development over time will be represented by the year-on-year development in 2011 and 2012 and we will benchmark the performance of the best industrial enterprises according to ownership (the best domestic private industrial enterprises and the best foreign private industrial enterprises active in the Czech Republic).

\section{Results of the application of a classic (standard) financial analysis}

The selection of indicators for the standard financial analysis is made according to individual constituent indicator groups affecting individual areas of the financial situation (aspects of the financial health) of an enterprise (Brealey and Myers, 2002). The most commonly occurring groups of indicators are those of profitability, liquidity, activity and indebtedness. Indicators are often selected within individual indicator groups subjectively and it is generally not stated why individual indicators are included in the analysis. Doubling is also common in the choice of indicators, when selected indicators have the same or a very similar information capability (most commonly indicators in the indebtedness group, when the indicators of Debts/Equity, Equity/Debts and Equity/ Assets are used simultaneously). A comprehensive indicator of economic profit in which risk is integrated is not used in this analysis. Certain bankruptcy and credibility models (for example Altman's model, the IN05 index etc.) are generally used and calculated to offer a comprehensive statement of the financial health of an enterprise.

It is clear from the calculated indicators in Table 1 for 2012 that foreign-owned companies achieve better results in return on equity (ROE) in terms of profitability indicators. Production power (ROA) and margins (ROS), however, show more reliable values among domestic-owned industrial enterprises. Here we have 
three indicators, in which domestic enterprises are better in two and foreign in one.

We are faced with the problem of an overall evaluation of the profitability group as a whole. In practice, it is dependent on the experience of the analyst who conducts the analysis. A similar situation would occur for other groups of indicators if we did not have only one indicator here.

We again come across the problem of the experience of the analyst in making an overall statement when domestic enterprises are better in two groups and foreign enterprises in two. This problem is often resolved in practice by applying selected bankruptcy and credibility models, the nature of which means that they are multi-criteria assessments of the financial health of an enterprise. The selection of indicators and their weights is not made subjectively in these models; instead, the function for an aggregate statement regarding the performance of the enterprise under consideration is determined from empirical data using mathematical/statistical methods (for example, discrimination analysis).

In our case, we chose the IN05 model (see Table 2), which is able to differentiate with a high level of probability ( 80 percent) enterprises with a positive economic profit value (i.e. the inclusion of risk enters the evaluation of the performance of an enterprise through the application of this index). As for the composition of indicators that the IN05 function includes, we work with the indicator of interest coverage (EBIT/cost interest) in addition to the above-mentioned indicators. In our case, we do not know cost interest, but because the best industrial enterprises for both groups are those in which there is a predominance of financing using equity and we can assume that production power is sufficiently high to ensure it is worth borrowing from the bank, we will count on a problem-free value of interest coverage of 9 . The criterial values of IN05 are 1.60 and 0.90 . If the value of IN05 is lower than 0.90 , the enterprise is probably not prospering (Neumaier, Neumaierová, 2004). An IN05 value of higher than 1.60 puts an enterprise into the zone of prosperity. Between 1.60 and 0.90 an enterprise finds itself within the grey zone, with an undecided situation as regards the creation of value. The result of the IN05 calculation shows that both groups of companies lie somewhere around the boundary between the grey zone and prosperity. In terms of IN05 values, foreign enterprises came out a little better than domestic enterprises in 2011, whilst in 2012 it was the other way round. We can see in this example that credibility and bankruptcy indicators are merely orientational in nature and are unable to replace a detailed financial analysis and calculation of economic profit. This is the disadvantage of IN05 and all other credibility and bankruptcy models (for example, Altman, 2000). Alongside the high probability of identifying positive economic profit, the advantage of IN05 as opposed to other models is that it does not use indicators based on market value; it suffices with easily accessible financial quantities and its application is not complicated.

\section{Results of the application of the INFA financial analysis}

The INFA financial analysis works in a short-term and long-term timescale with a single apical indicator: the criterion of the performance of the enterprise. In the short-term timescale (yearly), on which we concentrate in our financial analysis, the apical indicator is economic profit (EVA, see Figure 2) and in the long-term it is the flow of economic profits (Net Present Value, NPV). The sole apical indicator provides the owner an overall statement of whether his enterprise is or is not financially healthy or successful. For a deeper insight into the financial health of a company and justification for why a company is or is not successful, a financial analysis must be carried out in the form of the decomposition (origination of creation) of the apical indicator of financial health. This is done using three groups of indicators (see Figures 1 and 2). In this case, when interaction between indicators is taken into account or their relationships defined, there is the option of quantifying the influences of changes in constituent indicators on a change to the apical indicator.

Table 2 IN05

\begin{tabular}{|l|c|c|c|c|c|}
\hline Indicators & Weights & F11 & F12 & D11 & D12 \\
\hline Assets/Liability & 0,13 & 2,13 & 2,11 & 2,23 & 2,32 \\
\hline EBIT/Cost interest & 0,04 & 9,00 & 9,00 & 9,00 & 9,00 \\
\hline EBIT/Assets & 3,97 & 0,11 & 0,11 & 0,13 & 0,15 \\
\hline Revenues/Assets & 0,21 & 1,31 & 1,75 & 1,11 & 1,21 \\
\hline L3 & 0,09 & 2,36 & 2,19 & 1,90 & 1,80 \\
\hline IN05 & & 1,58 & 1,64 & 1,57 & 1,68 \\
\hline
\end{tabular}


Figure 2 Analysis of economic profit (EVA), ROE and re in INFA

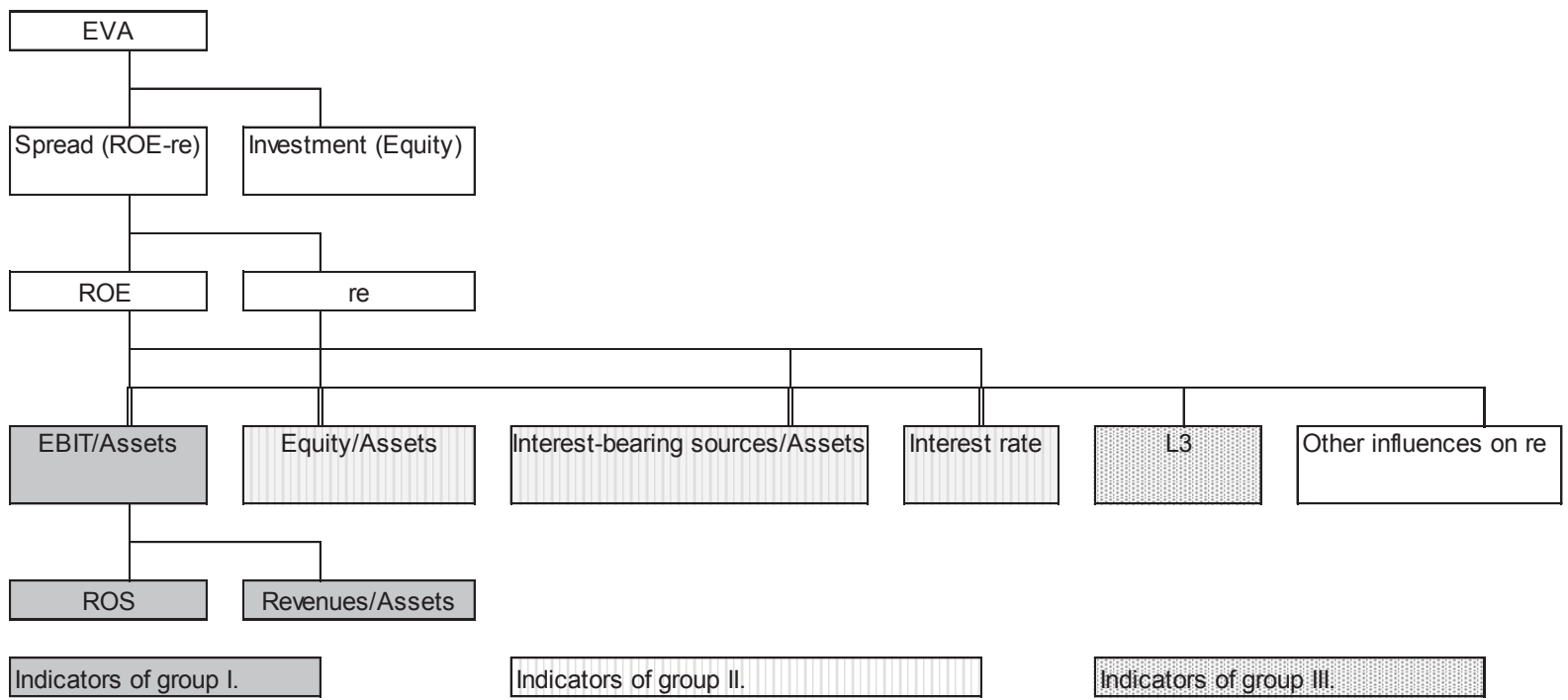

Source: Authors.

To provide a comparison of the approach of both concepts of analyses, we use the same six indicators that were used in the previous analysis (see Figure 2): Indicators of group I, Investment, Other influences on re).

INFA primarily tries to be aware of the relationships of the indicators we have available to us and through this to generate and explain a general picture of the financial performance of an enterprise.

The most comprehensive indicator of financial performance in our six is return on equity (ROE). If we look at Table 1 through the lens of Figure 2, it is evident that foreign-owned industrial enterprises are more effective in the year under consideration (their ROE value is higher).

Among the indicators that explain the value of ROE are the production power value (ROA) and the indebtedness indicator (we know the size of financial leverage through the share of equity in assets).

Domestic-owned enterprises have better production power, meaning they are more productive in creating company output. Foreign-owned enterprises have higher financial leverage, meaning that the reason for the better ROE at these companies is not the creation, but the division of company output (the effect of financial leverage).

The asset turnover indicator (Revenues/Assets) and return on sales (ROS) fall within the group of indicators that explain the ability to create company output and clarify the production power value achieved. It is clear that domestic-owned enterprises achieve better production power in consequence of higher returns on sales (ROS). The effect of this means that it outweighs the influence of the turnover of assets, in which foreignowned companies are best.

The above-mentioned indicators act on ROE and influence re. The final indicator, liquidity L3, only acts directly on risk (re). Liquidity values L3 monitor the financial stability under which the creation and division of company output take place. L3 is problem-free for both groups (it is neither too high nor too low).

It is clear that an INFA financial analysis is done causally and allows us to diagnose the reasons behind the return on equity (profitability) achieved (ROE) and the risks associated with the profitability achieved (re).

Economic added value is the indicator in which ROE and re become a part and is consequently the connecting line of financial controlling and financial risk. It is precisely this indicator that the INFA model uses as its apical indicator of the short-term (annual) performance of an enterprise. At the same time, the economic profit indicator is the connecting line for the management of short-term and long-term company performance. After all, the flow of economic profit is embodied by net present value, which INFA considers a criterion of company performance over the long term (Neumaier, Neumaierová, 2002).

The economic profit indicator is one of the absolute indicators and for this reason it is used in its relative format, when economic profit is related to equity. This brings us towards a spread with a shape that exhibits the 
difference between the ROE value and the rate of the alternative cost of equity (re). The spread is a relative indicator that shows by how many percent the profitability actually achieved by an enterprise (ROE) exceeds the profitability corresponding to the risk run. The spread is the apical indicator that we compare for both groups over a year.

We see from Table 1 that foreign-owned enterprises are more effective, achieving a higher spread value. In spite of the fact that foreign-owned companies show higher risk, their ROE is so much higher that the overall spread is more favorable for them.

Both groups improved their financial performance year-on-year. It is worth noting that in spite of the fact that the absolute size of EVA rose in both groups, it was created in 2012 with almost half the equity and a considerably better spread, meaning that the intensive dimension of the creation of economic profit became stronger. Companies with private foreign owners were helped in achieving a better spread in 2011 by the lower level of risk, while return on equity was almost identical in that year for both groups. Private domestic industrial companies were also able to boast higher production power in 2011, the cause of this being better return on sales (ROS). The EVA calculation stretches beyond the framework of financial accounting, but the fact that INFA deals with the roots of risk and tries to estimate the alternative cost of equity using financial accounting data means that it broadens the analytical possibilities of the use of financial accounting data.

\section{Comparison of results}

The classic financial analysis indicator does not provide a view of the risk under which company profitability is generated. The application of the IN05 credibility/ bankruptcy index is the only time in which risk is indirectly drawn into the evaluation. The results of the application of any credibility or bankruptcy model are only orientational in nature, however, meaning that they apply with a certain degree of probability. Moreover, a classic financial analysis does not resolve the relationship and interaction between indicators, either between individual groups of indicators or within them (for example, it does not deal with the relationship of ROA, ROE, ROS). The result of this is that it is unable to interpret the situation in which the development of particular indicators shows improvement, whilst that of others shows deterioration. At the same time, it does not allow the influence of the change of each indicator to be projected in a change of the apical indicator of the indicator system. There is no opportunity to apply any of the methods of quantifying the influence of a change of constituent indicators on the apical indicator (for example, logarithmic method or functional analysis).

INFA enables all of the above. It offers a clear conclusion as regards company performance and takes profitability and risk into account. Moreover, we could liken it to the zone that stands before a detailed causal analysis of the reasons for this situation. For example, the use of assets showed to be the weakest point for domestic-owned industrial enterprises. At the same time, the crest of earnings among these enterprises is able to bring more operating profit and lead to better production power among private domestic companies.

\section{Management results}

The practical impact of our work is to present a tool that allows entrepreneurs and managers at enterprises to better run their businesses. Work with the INFA method is shown using the example of an analysis of the financial performance of the best industrial enterprises in the Czech Republic with domestic and foreign owners. Apart from this, the use of the INFA method can help in the management of an enterprise in various ways:

- In the evaluation and explanation of the year-on-year development of an enterprise (change of economic profit over time);

- In the evaluation and explanation of the difference in the financial performance of an enterprise in comparison with the sector (comparison of the relative economic profit of the enterprise as opposed to the values which are characteristic for the sector or the best enterprises in that sector);

- In a comparison of the financial performance of an enterprise and its competitors (explanation of the difference in relative economic profit in comparison with a competitor);

- In an evaluation of fulfilment of the company plan (a comparison of the values of economic profit required by the plan and those actually achieved).

\section{Conclusion}

The INFA financial analysis is able to judge the financial situation more comprehensively than a classic financial analysis. This hypothesis was confirmed using a comparison of the information capability of both types of analysis.

INFA clearly separates the creation of EBIT, its division and relations of the lifetime of assets and liabilities. INFA does not require an experienced analyst, in that he or she must trust the assumptions carried into INFA 
and accept a new way of looking at an assessment of financial performance. This should not be a problem when you consider that INFA is not a black box, like the credibility and bankruptcy models, which are generally trusted. When using methods that quantify the influences of the development of constituent indicators on the development of the above indicator within INFA, it is practically "only" a matter of applying user-friendly SW. A comprehensive and causal new view of company performance, interwoven by the management of performance and risk, provides those that use INFA with the chance to generate a more accurate depiction of the financial situation and then have the scope for better decision-making. At the same time, it does not place additional demands on data and suffices with data from financial accounting, in the same way as a classic financial analysis. We consider the broadening of the analytical possibilities of financial accounting data to be the competitive advantage of the INFA method.

\section{Literature}

Altman, E. I. (2000). Predicting Financial Distress of Companies: Revisiting the Z-score and ZETA ${ }^{\circledR}$ Models, (accessed July 1, 2012), [available at http://pages.stern. nyu.edu/ ealtman/Zscores.pdf]

Bonaci, C., Strouhal, J., Müllerová, L., Roubíčková, J. (2013). Corporate Governance Debate on Professional Ethics in Accounting Profession. Central European Business Review, 2(3): 30-35.
Brealey, R. A., Myers, S. C. (2002). Principles of Corporate Finance. Boston : McGraw-Hill/Irwin.

Neumaier, I., Neumaierová, I. (2002). Výkonnost a tržní hodnota firmy. Prague: Grada Publishing.

Neumaier, I., Neumaierová, I. (2004). Index IN 05, in Sborník príspěvků mezinárodní vědecké konference „Evropské finančni systémy “, ed. Červinek, P., Brno: Ekonomickosprávní fakulta Masarykovy university, 143 - 148.

Ministry of Industry and Trade, Czech Republic (2013). Financial analysis of the business sphere (in Czech), (accessed May 1, 2013), [available at http://www.mpo.cz/cz/ministr-a-ministerstvo/ analyticke-materialy/\#category238].

\section{Authors}

Assoc. Prof. Inka Neumaierová, Ph.D. Associate professor Faculty of Business Administration University of Economics, Prague nám. W. Churchilla 4, 13067 Prague 3, ČR neumaier@vse.cz

Ing. Ivan Neumaier Analyst

Ministry of Industry and Trade of the Czech Republic Na Františku 32, 11015 Prague 1, ČR neumaier@mpo.cz 